\title{
ST DENYS' CONCEPT OF INITIATION \\ IN DE DIVINIS NOMINIBUS: A PARADOXICAL CASE
}

\begin{abstract}
Summary: In this paper, I am trying to analyze and interpret key passages of The Divine Names which concern Denys' theory of intitiation into the Christian mysteries. This analysis shows that Denys put forward Christian dogma as articulated in Neo-Platonic ontological terms; and that he understood initiation essentially as an advancing into the infinity of God.
\end{abstract}

Key words: Denys the Areopagite, Proclus, initiation, illumination, mystical union, Neo-Platonic ontology

\section{PROPOSITION}

The still unidentified Christian and Neo-Platonic mystic St Denys the Areopagite (floruit cca 500) often speaks about initiation in his most elaborate systematic positive

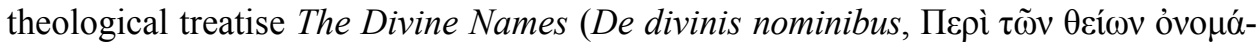
$\tau \omega v)$. In this paper, I would like to inquire into what he precisely means by "initiation" in this very seminal work, which directly influenced St Maximus the Confessor, Eriugena and the Saint-Victorians, to name only a few important - or even epochal early medieval theologian-philosophers. As is known, Denys' life work later became one of the chief authorities even for St Thomas Aquinas' Summa theologiae.

In a first approach, it seems that for Denys, "to initiate" - chiefly myeō, but also tele $\bar{o}$ and sometimes probably even anagō - is the traditional and formal act of teaching the uninitiated rationally articulated theological doctrines which they are unable to discover by their own reasoning. In this sense, initiation is a moral obligation to be fulfilled by the mystically inspired teacher as (s)he transmits knowledge as systematically as possible, concerning God and the relationship He entertains with Creation. This may be termed the positive theological stage of the Dionysian process of initiation. 
In a second approach, however, it turns out to be God, conceived as the NeoPlatonic Good itself, who carries out a more radical - or even infinite - act of initiation when the believer has reached a point where the intellectual irradiation of the Good is already perceivable. This, on the other hand, is also an act of participation (met$o k h \bar{e}$ ) in the Good, or even, ultimately, the mystical union (henōsis) with God. This may be termed the negative theological and mystical theological stage of the process. In fact, however, initiation is a multi-faceted concept emerging, under different names, in various and numerous Dionysian contexts, all of which ultimately describe some aspect or stage of the unio mystica.

The present paper intends, first, to discuss the different stages, modes, and meanings of the act of initiation on the basis of De divinis nominibus. Although Denys developed a - somewhat different - doctrine of initiation also in The Celestial Hierarchy (Chapter 7) and in The Ecclesiastical Hierarchy (Chapters 2 and 4-6), our focus will be restricted here to the text of The Divine Names, a work rich enough in itself, and we shall only occasionally refer to other parts of the Corpus Dionysiacum. This discussion will show, hopefully, that for Denys, initiation is part and parcel of a - paradoxical - theology of theophany, participation, communion, and mystical union; and that Denys' entire practical theological intention is one of initiation and anagogy.

Second, I shall also try to reconstruct the outlines of the Platonic and NeoPlatonic conceptual framework which is a major source of inspiration for Denys' scheme of initiation; from which it probably derives; and in which it is, in any case, deeply embedded.

\section{THE TECHNICAL TERMS AND THE RELEVANT PASSAGES REFERRING TO INITIATION}

In The Divine Names, Denys uses two or three key terms, and their derivatives, when describing the act of Christian initiation. In the first place, the general word myeo refers to an act of initiation and instruction in the divine mysteries. In other Dionysian texts, all the derivatives of this word will be found as well (myēsis: initiation; mystēs and hieromystēs: initiate; amystos and amyētos: uninitiated; mystagōgeō: to initiate). Interestingly, myeō occurs only in the first, second and fourth chapters of The Divine Names: in 1.3, 4 (two times) and 8; in 2. 4 and 9; in 3.1,2 and 3; and finally, in 4. 2 and 5.

Second, tele $\overline{0}$ - "to celebrate the rites of initiation, in the particular sense of bringing the initiate to perfection" - occurs only once in The Divine Names, in 1.3, while the nominal form telete - "the rites of initiation" or "sacrament" - is just one of the most important terms in The Ecclesiastical Hierarchy, especially in the introductory part of the third chapter, which concerns the mystical relevance of communion (koinonia and synaxis). Here, the dominating sense of the term is, essentially, "a sacred act which produces a union with God". ${ }^{\text {. }}$

\footnotetext{
${ }^{1}$ In the preceding part of The Ecclesiastical Hierarchy, Denys examines the question of how a

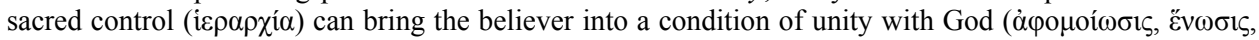


Finally, the less specific anagō, together with its nominal pair anagogēe, is often applied in the technical sense of a mystical elevation, lifting up, ascent or initiation into the divine realities, ${ }^{2}$ as is the case in 1.3 ; in 3.1 ; in 4. 2,9 and 12; and in 5.9 and 7. 1 of The Divine Names. It will be seen from this - hopefully complete - enumeration of the relevant passages that Chapter 4 of our ground text is, as it were, the locus by excellence where Denys deals with the question of initiation.

\section{PRECONDITIONS TO INITIATION}

In 1. 8, Denys warns us that the uninitiated (amystoi, amyettoi) should not even be allowed to listen to a rational exposition and explanation of the divine names deriving from Scripture and tradition. Then again, in the closing section of Chapter 1, Timothy is warned that he must protect (phylaxai) the divine doctrine from the uninitiated and should not communicate these teachings with them at all. Ta theia just must be kept secret and out of reach of whoever is not a Christian because outsiders - for a lack of understanding - would turn the mystical doctrine and practice into an object of derision. Further, non-believers do not deserve initiation also because they would be unwilling to accept the authority of the Scripture, and to yield to Christian moral theological and ecclesiastic precepts.

So while Christianity is the religion of a community, this religious community is a closed fellowship; and initiation is a "leading in" which is actually reserved only for those who have already been inside the community from the very beginning, one way or another. This concept of initiation is, hence, not universal but restricted in scope, and very personal in character; in fact, it can only produce the deepening of a faith and understanding which have already been there, which have already been received by a disciple, from a teacher. It is, as it were, an upgrading.

There is a further preliminary qualification of the process in 3.3 , where the praise of Hierotheos, Denys' unknown teacher - perhaps to be identified with Proclus $^{4}$ - crosses over into a description of initiation. Here, the main point is that initiating others into the mysteries of faith is a moral obligation incumbent upon the initiate. Initiation is, hence, the execution of a duty, whereby a teacher imitates, on a finite human scale, the unstinting effusion of divine bounty, of God conceived as the Good, since "...the law tells us to learn everything granted to us and to share these treasures generously with others". 5

$\theta \varepsilon \dot{\varepsilon} \omega \sigma \iota \varsigma ;$ see Chapter 2). Chapter 3 offers a symbolic interpretation of the events of communion (

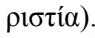

${ }^{2}$ The verb prosago is also used in the same sense.

${ }^{3}$ This enumeration is based on the Greek word index of B. R. SuCHLA's edition of the corpus (Corpus Dionysiacum I: Pseudo-Dionysios Areopagita, De divinis nominibus. Berlin - New York 1990), and on a semantic analysis of all the passages in which at least one of the key terms occurs.

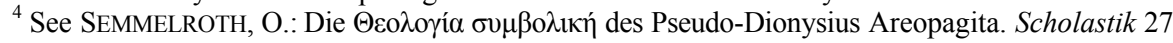
(1952) $1-11$

${ }^{5}$ LuiBHeID, C. (transl.): Pseudo Dionysius, The Complete Works. Foreword, notes and translation with collaboration by P. ROREM [The Classics of Western Spirituality]. New York 1987, 71. 
Strict exclusion of outsiders but a divinely modelled obligation to support insiders are therefore the moral prerequisites of initiation for Denys.

\section{THE FIRST STAGE OF INITIATION IN DENYS' SCHEME}

According to 1.4 of The Divine Names, the act of myesis takes place in a twofold manner. First, right now, in this world, in proportion to our intellectual faculties, in accordance with the Scripture, which is faithfully reproduced and canonised by the hierarchical tradition. This mode of initiation represents spiritual realities through sensible objects. It is a more rudimentary and somewhat misleading process of myessis, a kind of reduction, which hides away the infinitely remote supra-essential realities in the guise or semblance of immanent things, and invests the transcendent formless things with definite forms. In doing so, it "multiplies", and therefore inevitably misrepresents the absolute divine simplicity in numerous compound symbols.

In a similar vein, we learn from 1:8 that in sacred places, the initiates and the prophets are divinely enlightened by certain apparitions (phasmata), which also establish new divine names. These metaphorical names will name that which is beyond all names, will give form to that which is itself formless, and will vest it with anthropomorphic traits. Here, apparently, the initiates receive further introduction into divinity by a more immediately divine initiative. Hence it seems to be the case that there are gradations of initiation or, better, initiation is a never-ending procedure, an infinite approximation in this world. Instigated by the effusion of inexhaustible divine bounty, initiation is always in further progress. This mode of initiation is closely linked up with the theory of theophany as a reduced representation of God, receivable by a finite intellect.

So the several modes of a preliminary initiation in this world seem essentially symbolic acts only - Denys' approach here resembles Maximus' interpretation of the Holy Mass in the Mystagogy. In this conception, that which is ontologically apparent in God is rationally articulate for the theory, whereas that which is part of the divine kernel is hidden away from human intuition, while there is still an intimation that the apparent and the concealed are essentially related. This kind of symbolism, however, goes not further than an allusion: we are only pointed to the full secret reality of God. Which prompts us to proceed to a second stage of initiation.

\section{THE SECOND STAGE OF INITIATION}

Hence there is going to be an initiation in a second instance, or of a second order, in salvation, in patria, when we have become indestructible and godlike (christoeideis), as Denys puts it in 1.4 of The Divine Names. In this eschatological condition, the beatified souls enjoy God's presence by pure contemplations (theōria) of theophanies. This implies that the minds partake (metekhontes) of an intelligible enlightenment (noètēs phōtodosias), as well as of a supra-noetic (hyper noun), unknowable union with God, 
by receiving unexplainably an intellectual irradiation from God, beyond the rational capacities of the mind to understand. Hence on the one hand, the mind contemplates God ab extra, while on the other, it also partakes in God.

This theosophy so far has an utterly paradoxical character: the saving events do take place although in principle they cannot take place - in other words, they imply their own impossibility insofar as the mind is in God and outside God, there and not there at the same time; it partakes in a God who is unpartakeable; ${ }^{6}$ it reaches God who is unreachable in all rationally understandable ways; and the soul depends on its mind to reach a union with God beyond mind.

Next, in 2. 4, an important elaboration explains that the initiates (hieromystai) understand how the three divine hypostases relate to each other in the one divine essence. This complex doctrine of the henōseis and diaphorai within the supra-divine Godhead (hypertheotess) - a combination of negative and mystical theology - is important to us because it gives us insight into what kind of intellectual potential the initiates dispose of, and what sort of theological intuition they are able to teach to the still uninitiated. Conveying essentially the Proclean fundamental ontology of the One, Denys proposes here that the initiates' understanding is really the highest-ranking intuition into the structure of the divinity. This exposition of Dionysian structural theology differentiates between a hyperbolically transcendent fundament (or kernel), and a trinitarian superstructure, within God. The passage in question is also an example of how Denys initiates us readers into the divine mysteries - namely, by guiding us as high as possible along the still intelligible and rationally articulate realities in God. But beyond a certain point, suggests our author, human effort turns pointless. It is at this point that the Good itself shall intervene. ${ }^{7}$

\section{THE INTERVENTION OF THE GOOD IN A (NEO-)PLATONIC CONCEPTUAL FRAMEWORK}

It emerges from 4. 5-6 of The Divine Names that the real, ultimate initiation is carried out by the Good:

4. 5: The Good is described as the light of the mind because it illuminates the mind of every supra-celestial being with the light of the mind, and because it drives from souls the ignorance... It gives them all a share of sacred light. ... At first it deals out the light in small amounts and then, as the wish and longing for light begin to grow, it gives more and more of itself, shining ever more abundantly... and always it keeps urging them onward and upward as their capacity permits.

\footnotetext{
${ }^{6}$ In the theory of participation in God as expounded in 2. 5-6 of The Divine Names, the multitude partakes in God without participation (amethexia; see also 4.7 and 13. 2). The idea comes, no doubt, from Proclus' The Elements of Theology, 23-24.

${ }^{7}$ The following passages are also relevant descriptions of this stage of initiation: 3. 1 and 4. 2-4.
} 
4. 6: ... it is the presence of the light of the mind which gathers and unites together those receiving illumination. It perfects them. It returns them [epistreptikē ] toward the truly real. It returns them from their numerous false notions and, filling them with the one unifying light, it gathers their clashing fancies into a single, pure, coherent, and true knowledge. ${ }^{8}$

To judge by these passages, it is ultimately the unmediated influence of the Good which is able to and which is also bound to elevate the minds - for good. The three main operations of God conceived as the Good are illumination, elevation, and unification - but apparently, these three operations are only aspects of one and the same final saving act. The proposition that the Good elevates the minds signifies that initiated minds will have to go up systematically as they obey the overpowering "mind drain" of the Good or, in other words, that they just will leave the position they originally occupied in the hierarchical scale of being. Hence an almost automatic elevation takes place under the irresistible influence of the Good: the minds must ascend and abandon the place which has been assigned to them originally; and apparently, this is seen by Denys as an endless ascent into the infinity of God.

Further, the Good not only elevates the minds but also turns them (epistrephei) towards "truth". Epistrophe is in origin a Plotinian term, also used by Proclus, which refers to the perfection of an effect by virtue of its efficient cause - as it is only by "turning back" towards its cause that a thing can be completed and perfected (cf. Elements of Theology 31-39). This turning back is at the same time an elevation and a going back to the source, without which an entity may not realise the fullness of its essence - i.e., without which its existence does not have a meaningful end or destination. By reason of this parallelism between Proclean and Christian doctrines, a niche is opened for Denys to apply Neo-Platonic ontology onto Christian moral theology and eschatology, or to put forward Christian dogmas on a Neo-Platonic footing.

As a further point, Denys borrows from Proclus even the idea that efficient causes also unify their effects. Hence it is legitimate to say that the entire Dionysian doctrine concerning the operations of the Good - in the theory of initiation - derives from Proclus' scheme of the causality of the One as it is expounded in the Elements of Theology. On the other hand, the designation of the Good as the ultimate source of intellectual illumination, in the above-cited passages, openly refers to Plato's epistemological scheme as described at the end of Book 6 in the Republic (507b-511e). This statement brings us to a conclusion.

\section{CONCLUSION}

The attentive reader will find that a number of Classical Greek religious technical terms (epopteia, myēsis, epiphaneia) in Denys' text historically go back to the terminology of pre-Christian pagan initiation cults and religious rites. This, however, is

\footnotetext{
${ }^{8}$ LUIBHEID (n. 5) 75-76.
} 
inevitable - a pre-existent vocabulary is at his disposal on which he freely draws. It is more important for us here to spot and interpret the direct Platonic and Neo-Platonic references and ideas in Denys, and to offer an interpretive frame for his entire theory of initiation. ${ }^{9}$ The Neo-Platonic argumentative mechanism and philosophical apparatus detectable in The Divine Names appears as a useful tool in the logical articulation of the Christian dogma, and it seems that precisely this was Denys' hidden ideological agenda - to show that Platonism deserves saving because it is able logically to support the theory of divine saving, i.e., Christian soteriology. In essence, then, Denys' scheme of salvation is a scheme of Platonic intellectual illumination, which emphasises the ultimate destitution of the human mind and its reliance on, and necessary abandon to, the Good; because during the ascent, the mind's intellectual faculties gradually go out as it is about to reach the precondition of all reality, God. This upward mobile epistemological and metaphysical scheme is at the same time a dynamic theory of initiation, in which the highest stage is an open and infinitely deep horizon. The gradual elevation and admission of the mind into this infinity implies that God is ready to open up His hindmost reserves and allow man to advance from His periphery towards His supra-essential centre. That no precise ending of this advance is designated by Denys is a token that he takes God's infinity in the proper sense - whereby the Creator's supernatural character is conserved while still the most is offered to the creature. This theory of initiation, then, presupposes a complete detailed theology of redemption in which initiation takes place, in essence, by a saving admission into God Himself.

Miklós Vassányi

Department of General Humanities

Károli Gáspár University of the Reformed Church

Budapest, Hungary

vassanyi.miklos@gmail.com

\footnotetext{
${ }^{9}$ Some further important (Neo-)Platonic terms coming to the fore in The Divine Names are $\varphi \alpha \dot{\sigma} \mu \alpha$ and $\dot{\varepsilon} \pi \circ \pi \tau \varepsilon \dot{v} \omega(1.8)$. As far as $\varphi \dot{\alpha} \sigma \mu \alpha$ is concerned, we refer to Plato's Phaedrus, where the initiated soul - if it imitates God properly - is bound to see beatifying apparitions, before descending into the body

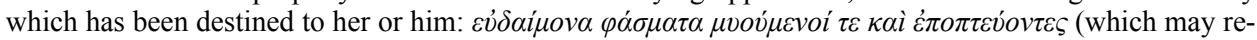
fer to the intellectual contemplation of the ideas; 250c3). Further, Iamblichus in De mysteriis 2. 2, defin-

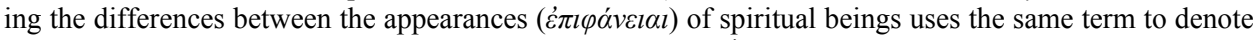

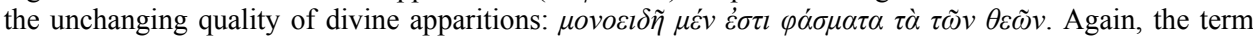
comes up in the sense of "divine apparition" in Proclus' In Alcibiadem (ed. WeSTERINK, Procli In Alci-

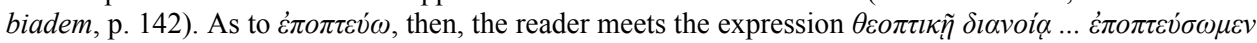

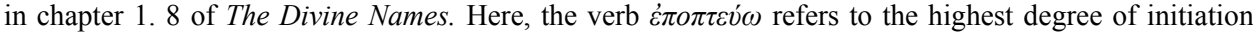
(epopteia) just like it does in the vocabulary of the classical Greek mystery religions. Plato also uses the same verb in the Phaedrus to describe how the soul contemplates the simple and divine apparitions: $\delta \lambda \dot{o}-$

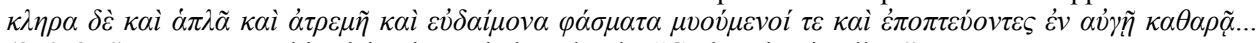
$(250 \mathrm{c} 2-4)$. For Denys, this vision is carried out by the "God-seeing intellect".
} 